\title{
FAKTOR RISIKO KEJADIAN FILARIASIS DI WILAYAH KERJA PUSKESMAS SABAK BARAT KABUPATEN TANJUNG JABUNG TIMUR PROVINSI JAMBI TAHUN 2017
}

\author{
Eti Kurniawati, Sugiarto,Teguh Prastyo \\ Program Studi Kesehatan Masyarakat STIKES Harapan Ibu, Jambi \\ Email : kurniawatieti620@yahoo.com
}

\begin{abstract}
ABSTRAK
Penderita filariasis di wilayah kerja Dinas Kesehatan Provinsi Jambi Tahun 2016 berjumlah 267 orang. Sedangkan di Kabupaten Tanjung Jabung Timur jumlah penderita filariasis berjumlah 58 orang. Penelitian ini merupakan penelitian kuantitatif dengan pendekatan case control yang bertujuan mengetahui faktor risiko kejadian filariasis di Puskesmas Sabak Barat Kabupaten Tanjung Jabung Timur. Populasi kasus adalah seluruh orang yang dinyatakan positif filariasis berdasarkan hasil survei darah jari pada tahun 2015 yang tercatat di Puskesmas Sabak Barat berjumlah 51 orang. Sedangkan populasi kontrol orang yang berdasarkan hasil survei darah jari pada tahun 2015 dinyatakan negatif filariasis yang bertempat tinggal di wilayah kerja Puskesmas Sabak Barat. Perbandingan jumlah sampel kasus dan kontrol adalah 1:1. Analisis data dalam penelitian ini menggunakan analisis Univariat dan Bivariat Hasil penelitian menunjukkan 52,9\% ada genangan air disekitar rumah, 59,8\% responden tidak menggunakan obat anti nyamuk saat tidur malam, 47,1\% responden tidak menggunakan kawat kasa, dan 45,1\% responden memiliki kebiasaan keluar malam. Ada hubungan antara genanggan air ( $\mathrm{p}$-value $=0,017, \mathrm{OR}=2,857)$, penggunaan obat anti nyamuk ( $\mathrm{p}$-value $=$ $0,015, \mathrm{OR}=2,073)$, penggunaan kawat kasa ( $\mathrm{p}$-value $=0,003, \mathrm{OR}=3,684)$ dan keluar malam $(\mathrm{p}$-value $=$ $0,047, \mathrm{OR}=2,417$ ) dengan kejadian filariasis. Disarankan kepada masyarakat untuk menggunakan obat anti nyamuk pada saat tidur, menggunakan kawat kasa, tidak keluar malam dan menggunkan baju panjang saat keluar malam.
\end{abstract}

Kata Kunci: Filariasis, Genangan Air, Obat Anti Nyamuk, Kawat Kasa, Keluar Malam

\section{ABSRACT}

Patients with filariasis in the region of Jambi Provincial Health Office 2016 amounted to 267 patients. Number of patients with filariasis in East Tanjung Jabung totaling 58 patients. This study is a quantitative research with case control approach that aims to identify risk factors incidence of filariasis in Sabak Health Center East Tanjung Jabung Barat. The population of the case are all those who tested positive for filariasis based on survey results finger blood in 2015 were recorded in health centers West Sabak amounted to 51 people. While the control population-based survey in 2015 finger blood tested negative filariasis reside in Puskesmas Sabak West. Comparison of the number of samples of cases and controls was 1: 1. Analysis of the data in this study using univariate analysis and Bivariat. The results showed $52.9 \%$ no puddles around the home, $59.8 \%$ of respondents did not use mosquito repellent during the night, $47.1 \%$ of respondents do not use a wire netting, and $45.1 \%$ of the respondents have the habit of a night out. There is a relationship between genanggan water ( $p$-value $=0.017, O R=2.857)$, use of anti-mosquito ( $p$-value $=0.015, O R=$ $2.073)$, use of wire netting ( $p$-value $=0.003, O R=3.684)$ and a night ( $p$-value $=0.047, O R=2.417)$ and the incidence of filariasis. It is suggested to people to use mosquito repellent during sleep, using wire netting, not a night out and use the long clothes when out at night.

Keywords: Filariasis, Puddle, Anti Mosquito, Wire Kasa, Out Tonight

\section{PENDAHULUAN}

Filariasis adalah suatu infeksi sistemik yang disebabkan cacing filaria dewasa yang hidup dalam kelenjar limfe dan darah manusia yang ditularkan oleh nyamuk. Penyakit ini bersifat menahun dan bila tidak mendapatkan pengobatan akan menimbulkan cacat menetap berupa pembesaran kaki (elephantiasis), pembesaran lengan, payudara, dan alat kelamin pada wanita maupun laki-laki. Penyakit ini menyebabkan produktifitas penderitanya penurun dan mengakibatkan kerugian yang tidak sedikit akibat kehilangan jam kerja yang disebabkan penyakit tersebut (Zulkoni A. 2011)

Data WHO menunjukkan bahwa 1,3 milyar penduduk dunia yang tinggal di 83 negara berisiko tertular filariasis dan $60 \%$ kasus berada di Asia Tenggara. Di Asia Tenggara jumlah kasus mencapai 851 juta penderita dan Indonesia menjadi negara dengan jumlah kasus tertinggi. Di Indonesia pada tahun 2005 sampai dengan 2009 berturut-turut jumlah kasus klinis yaitu 8.242 kasus, 10.427 
kasus, 11.473 kasus, 11.699 kasus, dan 11.914 Kasus . (Kemenkes RI 2010)

Survei pemeriksaan darah jari yang dilakukan dari tahun 2009 sampai 2012 terdapat Mf-rate $>1 \%$ yaitu Kelurahan Tegalrejo 2,3\%, Kelurahan Pabean 3,39\%, Kelurahan Bandengan 2,39\% dan Kelurahan Kertoharjo 4,18\%. Tahun 2011 Kelurahan Kertoharjo hasil Mf-rate-nya >1 \% yaitu sebesar 3,5\%. Tahun 2014 Kelurahan Kertoharjo masih mempunyai $M$ f-rate $9,7 \%$.

Banyak faktor risiko yang dapat menimbulkan kejadian filariasis. Salah satunya adalah faktor lingkungan yang sangat berpengaruh terhadap kepadatan vektor penularan filariasis. Faktor lingkungan dapat menunjang kelangsungan hidup vektor sehingga pengendalian dari faktor lingkungan masih sangat diperlukan. Oleh karena itu pengendalian vektor penularan filariasis perlu dikendalikan untuk membuat kondisi lingkungn tidak cocok sebagai perkembangan dan peristirahatan nyamuk, dimana pemberantasan tempat perkembangan nyamuk melalui pembersihan saluran pembuangan air, pengaliran air yang tergenang, penebaran bibit ikan pemakan jentik. Pemberantasan tempat peristirahatan nyamuk melalui pembersihan semak-semak dan pembersihan kandang ternak. (Widoyono, 2008)

Data Dinas Kesehatan Provinsi Jambi tahun 2016 menunjukkan bahwa jumlah kasus filariasis berjumlah 267 penderita. Dari 276 kasus filariasis sebanyak 188 penderita berjenis kelamin laki-laki dan 79 penderita berjenis kelamin perempuan. (Profil Dinkes Jambi, 2016)

Sedangkan jumlah kasus filariasis di Puskesmas Sabak Barat berjumlah 51 kasus dengan jumlah penderita berjenis kelamin laki-laki sebanyak 37 kasus dan perempuan sebanyak 14 kasus. ((Profil PKM Muara Sabak Barat)
Berdasarkan latar belakang penelitian, maka penulis tertarik untuk melakukan penelitian tentang "faktor risiko kejadian filariasis di wilayah kerja Puskesmas Sabak Barat Kabupaten Tanjung Jabung Timur Provinsi Jambi Tahun 2017”.

\section{METODE}

Penelitian ini merupakan penelitian kuantitatif dengan pendekatan case control yang bertujuan untuk mengetahui faktor risiko kejadian filariasis di Puskesmas Sabak Barat Kabupaten Tanjung Jabung Timur Provinsi Jambi Tahun 2017. Populasi kasus dalam penelitian ini adalah seluruh orang yang bertempat tinggal di wilayah kerja Puskesmas Sabak barat, yang dinyatakan positif filariasis berdasarkan hasil survei darah jari pada tahun 2015 yang tercatat di Puskesmas Sabak Barat berjumlah 51 orang. Sedangkan populasi kontrol adalah orang yang berdasarkan hasil survei darah jari pada tahun 2015 dinyatakan negatif filariasis yang bertempat tinggal di wilayah kerja Puskesmas Sabak Barat. Perbandingan jumlah sampel kasus dan kontrol adalah 1:1, sehingga didapatkan jumlah sampel sebanyak 102 sampel. Penelitian ini dilakukan di wilayah kerja Puskesmas Sabak Barat dan dilakukan pada bulan Maret 2017. Analisis data dalam penelitian ini menggunakan analisis Univariat dan Bivariat dengan melihat nilai OR.

\section{HASIL DAN PEMBAHASAN}

\section{Analisis Univariat}

Sebanyak 52,9\% ada genangan air disekitar rumah, $59,8 \%$ responden tidak menggunakan obat anti nyamuk saat tidur malam, $47,1 \%$ responden tidak menggunakan kawat kasa, dan $45,1 \%$ responden memiliki kebiasaan keluar malam.

Tabel 1. Hasil Analisis Univariat

\begin{tabular}{lcc}
\hline Variabel & Frekuensi & $\%$ \\
\hline Kejadian Filariasis & 51 & \\
Filariasis & 51 & 50,0 \\
Tidak Filariasis & & 50,0 \\
Genangan Air & 54 & 52,9 \\
Ada Genangan Air & 48 & 47,1 \\
Tidak Ada Genangan air & & \\
Penggunaan Obat Anti Nyamuk & 61 & 59,8 \\
Kurang Baik & 41 & 40,2 \\
Baik & & \\
Penggunaan Kawat Kasa & 48 & 47,1 \\
Kurang Baik & 54 & 52,9 \\
Baik & & \\
Keluar Malam & 46 & 45,1 \\
Kurang Baik & 56 & 54,9 \\
Baik & & \\
\hline
\end{tabular}




\section{Analisis Bivariat}

Hasil analisis bivariat menunjukkan bahwa ada hubungan antara keberadaan genangan air dengan kejadian filariasis di wilayah kerja Puskesmas Sabak Barat Kabupaten Tanjung Jabung Timur dengan p-value sebesar 0,017 dan nilai $\mathrm{OR}=$ 2,857. Ada hubungan antara penggunaan obat anti nyamuk dengan kejadian filariasis di wilayah kerja Puskesmas Sabak Barat Kabupaten Tanjung Jabung Timur dengan p-value sebesar 0,015 dan nilai $\mathrm{OR}=2,973$. Ada hubungan antara penggunaan kawat kasa dengan kejadian filariasis di wilayah kerja Puskesmas Sabak Barat Kabupaten Tanjung Jabung Timur dengan p-value sebesar 0,003 dan nilai $\mathrm{OR}=3,684$. Ada hubungan antara keluar malam dengan kejadian filariasis di wilayah kerja Puskesmas Sabak Barat Kabupaten Tanjung Jabung Timur dengan p-value sebesar 0,047 dan nilai $\mathrm{OR}=2,417$.

Tabel 2. Hasil Analisis Bivariat

\begin{tabular}{|c|c|c|c|c|c|c|c|c|c|}
\hline \multirow{3}{*}{\multicolumn{2}{|c|}{$\begin{array}{l}\text { Variabel } \\
\text { Independen }\end{array}$}} & \multicolumn{4}{|c|}{ Kejadian Filariasis } & \multirow{2}{*}{\multicolumn{2}{|c|}{ Total }} & \multirow{3}{*}{$\begin{array}{l}P- \\
\text { Value }\end{array}$} & \multirow{3}{*}{$\mathrm{OF}$} \\
\hline & & \multicolumn{2}{|c|}{ Kasus } & \multicolumn{2}{|c|}{ Kontrol } & & & & \\
\hline & & $\mathrm{n}$ & $\%$ & $\mathrm{n}$ & $\%$ & $\mathrm{~N}$ & $\%$ & & \\
\hline \multicolumn{10}{|l|}{ Keberadaan } \\
\hline \multicolumn{10}{|l|}{ Genangan air } \\
\hline Tidak Ada & & 17 & 33,3 & 30 & 58,8 & 47 & 46,1 & & \\
\hline \multicolumn{10}{|c|}{ Penggunaan Obat } \\
\hline Kurang baik & & 37 & 72,5 & 24 & 47,1 & 61 & 59,8 & 0,015 & 2,9 \\
\hline Baik & & 14 & 27,5 & 27 & 52,9 & 41 & 40,2 & & \\
\hline \multicolumn{10}{|c|}{ Penggunaan Kawat } \\
\hline Kurang baik & & 32 & 62,7 & 16 & 31,4 & 48 & 47,1 & 0,003 & 3,7 \\
\hline Baik & & 19 & 37,3 & 35 & 68,6 & 54 & 52,9 & & \\
\hline \multicolumn{10}{|l|}{ Keluar Malam } \\
\hline Kurang baik & & 29 & 56,9 & 18 & 35,3 & 47 & 46,1 & 0,047 & 1,1 \\
\hline Baik & & 22 & 43,1 & 33 & 64,7 & 55 & 53,9 & & \\
\hline
\end{tabular}

\section{Hubungan Keberadaan Genangan Air dengan Kejadian Filariasis}

Berdasarkan hasil penelitian, menunjukkan bahwa ada hubungan antara keberadaan genangan air dengan kejadian filariasis di wilayah kerja Puskesmas Sabak Barat Kabupaten Tanjung Jabung Timur dengan p-value sebesar 0,017. Hasil penelitian diperoleh nilai $\mathrm{OR}=2,857$, hal tersebut menunjukkan bahwa responden yang disekitar rumahnya terdapat genangan air berisiko 2,857 kali lebih tinggi terkena filariasis jika dibandingkan dengan responden yang disekitar rumahnya tidak ada genangan air.

Jarak terbang nyamuk pada umumnya adalah 1-2 Km. Jadi dengan keberadaan genangan air pada jarak tersebut akan mendekatkan manusia dengan nyamuk vektor filariasis sehingga risiko terkena filariasis pada orang yang tinggal dekat genangan air lebih tinggi dibandingkan orang yang tinggal jauh dari genangan air. Genangan air berpengaruh terhadap distribusi habitan vektor filariasis dan mata rantai penularannya karena mempengaruhi dan mendukung kepadatan nyamuk Culex. (Widiastuti AI, 2013)

Hasil observasi menunjukkan sebesar 52,9\% disekitar rumah ditemukan genagan air seperti tanaman air, got atau saluran air yang tidak lancar dan adanya rawa-rawa serta sawah, merupakan potensi untuk perkembangan dari nyamuk, dilingkungan nyamuk membutuhkan air untuk meletakan telurnya, keberadaan genangan air sebagai faktor risiko terjadinya perkembang biakan dari nyamuk. Keberadaan genangan air yang disebabkan pembuangan air limbah yang terbuka akan meningkatkan risiko penduduk yang tinggal di sekitarnya karena dengan adanya genangan air di sekitar rumah dapat meningkatkan populasi/kepadatan nyamuk yang merupakan vektor penular filariasis. Untuk itu disarankan kepada masyarakat untuk membersihkan tanaman air, menimbun genangan air, membersihkan selokan, mengalirkan air yang menggenang. 


\section{Hubungan Penggunaan Obat Anti Nyamuk dengan Kejadian Filariasis}

Berdasarkan hasil penelitian, menunjukkan bahwa ada hubungan antara penggunaan obat anti nyamuk dengan kejadian filariasis di wilayah kerja Puskesmas Sabak Barat Kabupaten Tanjung Jabung Timur dengan p-value sebesar 0,015. Hasil penelitian diperoleh nilai $\mathrm{OR}=2,973$, hal tersebut menunjukkan bahwa responden yang tidak menggunakan obat anti nyamuk pada saat tidur berisiko 2,973 kali lebih tinggi menderita filariasis jika dibandingkan dengan responden yang menggunakan obat anti nyamuk pada saat tidur malam.

Berdasarkan hasil penelitian menunjukkan bahwa sebanyak 59,8\% responden tidak menggunakan obat anti nyamuk saat tidur malam. Responden tidak menggunakan obat anti nyamuk dikarenakan obat anti nyamuk memberikan efek seperti panas dan kesat pada kulit. Selain itu adapula pernyataan responden yang menyatakan bahwa digigit nyamuk merupakan hal yang biasa, sehingga tidak ada upaya untuk melindungi diri dari gigitan nyamuk.

Selain manfaat dari obat anti nyamuk yang dapat menghindari dari gigitan ada beberapa orang yang memiliki kulit sensitif menggunakan obat anti nyamuk oles. Bagi masyarakat yang memiliki kulit sensitif dapat melakukan peningkatan pencegahan diri dari gigitan nyamuk lainnya. Bagi penderita dan masyarakat yang tidak memiliki kulit sensitif diharapkan menggunakan obat anti nyamuk ketika waktu senja hingga fajar. Oleh karena itu, sebaiknya responden dan mayarakat untuk menggunakan kasa ventilasi, memakai baju panjang dan memakai kelambu saat tidur supaya terhindar dari gigitan nyamuk.

\section{Hubungan Penggunaan Kawat Kasa dengan Kejadian Filariasis}

Berdasarkan hasil penelitian, menunjukkan bahwa ada hubungan antara penggunaan kawat kasa dengan kejadian filariasis di wilayah kerja Puskesmas Sabak Barat Kabupaten Tanjung Jabung Timur dengan p-value sebesar 0,003. Hasil penelitian diperoleh nilai $\mathrm{OR}=3,684$. Hal tersebut menunjukkan bahwa responden yang tidak menggunakan kawat kasa berisiko 3,684 kali lebih tinggi menderita filariasis jika dibandingkan dengan responden yang menggunakan kawat kasa.

Dalam penularan suatu penyakit hal yang tidak bisa diabaikan adalah interaksi antara manusia dengan perilakunya serta komponen lingkungan di sekitar manusia yang memiliki potensi menyebabkan penyakit. Pemasangan kawat kasa pada ventilasi akan menyebabkan semakin kecilnya kontak nyamuk yang berada di luar rumah dengan penghuni rumah, dimana nyamuk tidak dapat masuk ke dalam rumah. (Depkes RI, 2009)

Hasil penelitian menunjukkan bahwa sebanyak $47,1 \%$ responden tidak memasang kawat kasa di ventilasi rumahnya. Oleh karena nyamuk penular filariasis dapat menggigit di dalam rumah, maka tidak memasang kasa ventilasi memiliki kecenderungan yang tinggi untuk kontak dengan nyamuk penular filariasis di dalam rumah. (Depkes RI, 2008)

Berdasarkan hasil wawancara dengan responden saat penelitian kondisi rumah masih menggunakan kamar, sehingga hanya ada pintu dan jendela saja sebagai lubang udara. Selain itu ada penderita yang menyatakan alasan ekonomi, yaitu memasang kawat kasa berarti mengeluarkan uang lebih besar lagi.

Apabila dilihat dari kondisi lingkungan antara rumah dengan tempat perkembangbiakan nyamuk maka kelompok kasus memiliki persentase lebih besar dekat rawa-rawa. Maka dari itu untuk menurunkan tingkat populasi nyamuk yang masuk ke dalam rumah ventilasi harus ditutup. Apabila kondisi rumah tidak dapat di intervensi, maka proteksi diri harus ditingkatkan seperti menggunakan kelambu pada saat tidur atau menggunakan obat anti nyamuk.

\section{Hubungan Keluar Malam dengan Kejadian Filariasis}

Berdasarkan hasil penelitian, menunjukkan bahwa ada hubungan antara keluar malam dengan kejadian filariasis di wilayah kerja Puskesmas Sabak Barat Kabupaten Tanjung Jabung Timur dengan p-value sebesar 0,047. Hasil penelitian diperoleh nilai $\mathrm{OR}=2,417$. Hal tersebut menunjukkan bahwa responden yang memiliki kebiasaan keluar malam berisiko 2,417 kali lebih tinggi menderita filariasis jika dibandingkan dengan responden yang tidak memiliki kebiasaan keluar malam.

Kebiasaan responden untuk keluar rumah pada malam hari saat nyamuk Anopheles aktif menggigit akan meningkatkan risiko kejadian filariasis. Faktor tersebut terkait erat dengan spesies nyamuk yang ada. Berdasarkan hasil survei vektor yang dilakukan bahwa puncak kepadatan nyamuk terjadi pada pukul $20.00-21.00$. Oleh karena itu aktivitas keluar rumah pada malam hari meningkatkan frekuensi kontak dengan nyamuk. Kebiasaan keluar rumah pada malam hari berkaitan dengan intensitas kontak dengan vektor filariasis.

Untuk itu disarankan kepada responden sebaiknya membiasakan diri memakai baju panjang dan celana panjang serta memakai obat nyamuk oles pada saat keluar rumah pada malam hari. Hal 
ini untuk meminimalkan resiko tergigit nyamuk saat beraktivitas di luar rumah pada malam hari.

\section{SIMPULAN}

Ada hubungan antara keberadaan genangan air dengan kejadian filariasis di wilayah kerja Puskesmas Sabak Barat Kabupaten Tanjung Jabung Timur dengan p-value sebesar 0,017 dan nilai $\mathrm{OR}=2,857$. Ada hubungan antara penggunaan obat anti nyamuk dengan kejadian filariasis di wilayah kerja Puskesmas Sabak Barat Kabupaten Tanjung Jabung Timur dengan p-value sebesar 0,015 dan nilai $\mathrm{OR}=2,973$. Ada hubungan antara penggunaan kawat kasa dengan kejadian filariasis di wilayah kerja Puskesmas Sabak Barat Kabupaten Tanjung Jabung Timur dengan p-value sebesar 0,003 dan nilai $\mathrm{OR}=3,684$. Ada hubungan antara keluar malam dengan kejadian filariasis di wilayah kerja Puskesmas Sabak Barat Kabupaten Tanjung Jabung Timur dengan p-value sebesar 0,047 dan nilai $\mathrm{OR}=2,417$.

\section{SARAN}

Diharapkan Puskesmas melakukan pemberdayaan masyarakat dengan mengadakan kegiatan gotong royong secara rutin setiap minggu. Dengan adanya kegiatan gotong royong secara rutin dapat mengurangi tempat perindukan nyamuk. Menyerankan kepada masyarakat pada saat keluar rumah pada malam hari menggunakan pakaian panjang dan menggunakan obat anti nyamuk. Membagikan kelambu kepada masyarakat sehingga masyarakat dapat menggunakan kelambu pada saat tidur malam.

\section{DAFTAR PUSTAKA}

Akhsin Zulkoni, 2011, Parasitologi, Nuha Medika, Yogyakarta

Kementerian Kesehatan Republik Indonesia, 2010, Filariasis di Indonesia, Kemenkes RI, Jakarta

Widoyono, 2008, Penyakit Tropis epidemiologi, Penularan, Pencegahan, dan Pemberantasan, Erlangga, Semarang

Dinas Kesehatan Provinsi Jambi, 2016. Profil Dinas Kesehatan provinsi Jambi tahun 2015. Jambi

Puskesmas Muara Sabak Barat, 2016. Profil Puskesmas Muara Sabak Barat tahun 2015. Jambi

Ike Ani Windiastuti, dkk, 2013, Hubungan Kondisi Lingkungan Rumah, Sosial Ekonomi, dan Perilaku Masyarakat dengan Kejadian Filariasis di Pekalongan Selatan Kota Pekalongan, Volume XII, No 1, April 2013, hlm. 51-57

Depkes RI, 2009, Mengenal Filariasis (Penyakit Kaki Gajah), Ditjen P2 \& PL Depkes RI, Jakarta

Departemen Kesehatan Republik Indonesia, 2008, Epidemiologi Filariasis, Ditjen P2 \& PL Depkes RI, Jakarta.

Dinas Kesehatan Provinsi Daerah Tingkat I Jawa Tengah, 2011, Profil Kesehatan Provinsi Jawa Tengah Tahun 2010, Dinkes Provinsi Dati I Jateng, Semarang. 